\title{
Mild Chronic Hyponatremia and Osteoporotic Fractures Risk in Elderly
}

\author{
RALUCA ALEXANDRA TRIFANESCU1,2, DAN SOARE ${ }^{1}$, CATALIN CARSTOIU1,3, GHEORGHE POPESCU1,4, \\ ALINA MIHAELA PASCU ${ }^{5 *}$, VLADIMIR POROCH ${ }^{6,7 *}$, SEBASTIAN TOMA ${ }^{5}$, CATALINA POIANA ${ }^{1,2}$ \\ ${ }^{1}$ Carol Davila University of Medicine and Pharmacy, 37 Dionisie Lupu Str., 020021, Bucharest, Romania \\ ${ }^{2}$ C. I. Parhon National Institute of Endocrinology, 34-38 Aviatorilor Blv., 011863, Bucharest, Romania \\ ${ }^{3}$ University Emergency Hospital, Orthopedic Department, 169 Splaiul Independentei, 050098, Bucharest, Romania \\ ${ }^{4}$ Clinical Emergency Hospital, Orthopedic Department, 8 Calea Floreasca, 014461, Bucharest, Romania \\ ${ }^{5}$ Transilvania University of Bra'ov, Faculty of Medicine, 29 Eroilor Blvd, 500036, BraSov, Romania \\ ${ }^{6}$ Grigore T. Popa University of Medicine and Pharmacy, Faculty of Medicine, 16 Universitatii St., 700115, lasi, Romania \\ ${ }^{7}$ Regional Institute of Oncology, 2-4 G-ral Berthelot Str., 700483, lasi, Romania
}

\begin{abstract}
Low serum sodium levels were associated with increased prevalence of osteoporosis and fractures. The aim of the study was to assess the relationship between serum sodium and bone mineral density and/or osteoporotic fractures' prevalence in elderly people. A total number of 260 patients ( 23 men / 237 women), aged $66.5 \pm 12.8$ years, were retrospectively assessed. Serum sodium levels were measured in all patients. Bone mineral density (BMD) was measured by dual X-ray absorptiometry (DXA). Results: serum natremia was $140.3 \pm 4.4 \mathrm{mmol} / \mathrm{L}$; prevalence of hyponatremia was 7.3\%; frailty fractures were present in 117 out of 260 patients (45\%). Patients with fractures had lower serum sodium levels as compared to patients without fractures (139 \pm 3.9 vs. $141.5 \pm 4.6 \mathrm{mmol} / \mathrm{L}, p<0.001)$. Patients with osteoporosis $(n=179)$ also showed lower natremia as compared to patients with normal BMD and osteopenia $(n=81): 139.9 \pm 4.7 \mathrm{vs} .141 .2$ $\pm 3.8 \mathrm{mmol} / \mathrm{L}, p=0.035$. In patients admitted in the hospital for fractures $(n=92)$, prevalence of hyponatremia was $13.04 \%$. Hyponatremic patients had significantly higher prevalence of fractures $(73.7 \%$ vs. $42.7 \%$, $p=$ 0.0147 ) as compared to normonatremic patients. Odds ratio (OR) for fractures in patients with hyponatremia was 3.75 [95\% C.I.: 1.3-10.75], $p=0.0138$; OR for hip fractures in patients with hyponatremia was 3.65 [95\% C.I.: 1.38-9.64], $p=0.0089$. Both incidence and prevalence of hyponatremia increase with age, especially in patients treated with diuretics. Several clinical studies found an association between mild chronic hyponatremia in elderly and increased odds ratio of osteoporosis at the total and at femoral neck; the study also showed an increased odds ratio for all fractures and for hip fractures in hyponatremic patients. Elderly people at risk of osteoporotic fractures should have sodium serum measured.
\end{abstract}

Keywords: hyponatremia, osteoporosis, fall-related fractures, bone remodelling, frailty

Hyponatremia (serum sodium $<135 \mathrm{mmol} / \mathrm{L}$ ) is the most common electrolyte disorder [1-3], found in $2-4 \%$ of cases in general population, $7-11 \%$ in ambulatory elderly and $20-53 \%$ in hospitalized patients [3-8], due to agerelated abnormalities of water homeostasis [9]. Up to $20 \%$ of elderly patients with mild chronic hyponatremia, considered as asymptomatic in the past, were admitted in the hospital for falls and fall-related fractures $[9,10]$.

Recent data showed an association between hyponatremia and osteoporosis and between hyponatremia and falls and fractures independent of osteoporosis, age and gender [1, 11].

Initially, chronic hyponatremia was associated with cognitive dysfunction, impaired attention, unsteady gait, leading to falls; on the other hand, hyponatremia was recently proved to be directly involved in bone remodelling, by increasing osteoclastic activity and decreasing bone mineralization, decreasing bone mineral mass [12]. In some cases of hyponatremia-induced secondary osteoporosis, the effect on bone metabolism seemed to be partially reversible [13].

Hyponatremia was associated with falls and bone fractures especially in elderly women, users of thiazide diuretics and anti-depressant (selective serotonin reuptake inhibitors, SSRI) [1].

Also in men, hyponatremia was associated with up to a doubling in the risk of hip and morphometric spine fractures, independent of bone mineral density [14].
Sustained low extracellular $\mathrm{Na}^{+}$concentration was associated with a decrease in ascorbic acid uptake, an increase in oxidative stress, with direct stimulation of osteoclastogenesis, increased bone resorption and decreased bone mineral density [15, 16]. Hyponatremia had also a negative influence on endogenous ionic currents in fractured bones $[17,18]$, leading to impaired microfracture repair by decreasing osteoblastic activity, generating clinical apparent fractures [1].

Hyponatremic patients had elevated argininevasopressin (AVP) levels. Experimentally, AVP receptors, AVPrl $\alpha$ and AVPr2, were expressed both in osteoblasts and osteoclasts. AVP injection in wild type mice increased the formation of osteoclasts and reduced the formation of osteoblasts [19].

In a rat model of syndrome of inappropriate antidiuretic hormone secretion (SIADH), chronic hyponatremia exacerbated manifestations of senescence [20], reduced bone mass, thinned both trabecular and cortical bone, increased number of osteoclasts per bone area [3].

The aim of the study was to assess the relationship between serum natremia and bone mineral density and/or osteoporotic fractures' prevalence.

\section{Experimental part}

The relationship between hyponatremia and bone mineral density was retrospectively assessed in an observational, retrospective study on 260 Caucasian 
patients ( 23 men / 237 women), aged $66.5 \pm 12.8$ years (range 30-95 years), hospitalized either in a tertiary endocrine center for bone mineral density (BMD) assessment (group I, $n=168$ ) or in two orthopedics departments of emergency hospitals for hip and distal forearm fractures secondary to falls (group II, $n=92$ ). Self-reported fractures, confirmed by radiology were used in group I, while in group II data were extracted from patient's files, including radiology data. Mean postmenopausal period in studied women was $15 \pm 9.2$ years (range 0-37).

Hyponatremia was defined as a natremia level bellow $135 \mathrm{mmol} / \mathrm{L}$. Serum sodium was determined using clinical chemistry laboratories (normal range: $136-145 \mathrm{mmol} / \mathrm{L}$ ).

Body mass density (BMD) was assessed by dual X-ray absorptiometry (DXA - GE Lunar) in group l; in patients from group II, DXA was not performed, as the presence of a frailty fracture (distal forearm or hip fractures) proved severe osteoporosis.

The data were analysed with SPSS version 17.0. Parametric data were presented as means $\pm S D$, categorical variables as percentages (\%). Group differences in means were compared using Student t-test (for two independent samples). For categorical variables, differences were assessed using Fischer's Exact Test. Odds ratio (OR) analysis was used for assessing the risk of fractures in patients presented with hyponatremia. A value of $p<0.05$ was considered statistically significant.

\section{Results and discussions}

In our study group, the mean serum sodium levels was $140.3 \pm 4.4 \mathrm{mmol} / \mathrm{L}$ (range: $106-149 \mathrm{mmol} / \mathrm{L}$ ); prevalence of hyponatremia was $7.3 \%$ (19 out of 260). Mean serum total calcium levels was $9.4 \pm 0.5 \mathrm{mg} / \mathrm{dL}$ (range: 7.2-10.3 $\mathrm{mg} / \mathrm{dL}$ ); median PTH level was $48.1 \mathrm{pg} / \mathrm{mL}$ ( $25^{\text {th }}$ percentile: $34.1 \mathrm{pg} / \mathrm{mL}, 75^{\text {th }}$ percentile: $82 \mathrm{pg} / \mathrm{mL}$ ); mean $25 \mathrm{OH}$ vitamin D levels was $17.5 \pm 7.7 \mathrm{ng} / \mathrm{mL}$ (range: $4-42.1 \mathrm{ng} /$ $\mathrm{mL}$ ), with most of the patients presenting with vitamin $D$ insufficiency.

Frailty fractures were present in 117 out of 260 patients (45\%): vertebral fractures in 7 patients $(2.7 \%)$, distal forearm fractures in 21 patients ( $8.1 \%$ ) and hip fractures in 89 patients (34.2\%). Multiple fractures were recorded in 7 patients (vertebral plus distal forearm, hip fracture plus distal forearm).

Patients with frailty fractures $(n=117)$ were significantly older as compared to patients without fractures $(n=143)$ : $75.7 \pm 10.1$ years vs. $59.05 \pm 9.3$ years ( $p<0.001$, t test). They also showed significantly lower serum sodium levels as compared to patients without fractures $(139 \pm 3.9 \mathrm{mmol} / \mathrm{L}$ vs. $141.5 \pm 4.6 \mathrm{mmol} /$ $\mathrm{L}, p<0.001$, t test) (fig. 1).

Hyponatremia was present in $11.9 \%$ (14 out of 117 patients) with fractures versus $3.5 \%$ ( 5 out of 143 patients) without fractures ( $p=0.0147$, Fischer's Exact Test).

\begin{tabular}{|c|c|c|c|c|}
\hline & $\begin{array}{c}\text { Group A } \\
\text { Normal BMD }\end{array}$ & $\begin{array}{c}\text { Group B } \\
\text { Osteopenia }\end{array}$ & $\begin{array}{c}\text { Group C } \\
\text { Osteporosis }\end{array}$ & $\begin{array}{c}P \text { (groups } \mathrm{A}+\mathrm{B} \\
\text { vs. group } \mathrm{C} \text { ) }\end{array}$ \\
\hline n (\%) & $27(10.4 \%)$ & $54(20.8 \%)$ & $179(68.8 \%)$ & - \\
\hline Men/ Women & 0727 & $4 / 50^{\circ}$ & $197160^{\circ}$ & $0.16^{*}$ \\
\hline Age (years) & $52.9 \pm 8.6$ & $60.9 \pm 8.8$ & $70.3 \pm 12.2$ & $<0.0001^{* *^{-1-}}$ \\
\hline $\mathrm{Na}^{+}(\mathrm{mmol} / \mathrm{L})$ & $141.6 \pm 3.1$ & $141=4.2$ & $139.9 \pm 4.7$ & $0.035^{* * 7}$ \\
\hline $\begin{array}{c}\text { Hyponatremia (n } 7 \\
\%)\end{array}$ & $1(3.7 \%)$ & $2(3.7 \%)$ & $16(8.9 \%)$ & $0.19 *$ \\
\hline $\begin{array}{l}\text { No. of fractures, } \mathrm{n} \\
(\%)\end{array}$ & 0 & $6(11.1 \%)$ & $111(62 \%)$ & $<0.0001^{*}$ \\
\hline
\end{tabular}

Table 1

SERUM SODIUM LEVELS ACCORDING TO BONE STATUS (NORMAL / OSTEOPENIA / OSTEOPOROSIS) 
$3.7 \%)$, but without reaching statistical significance ( $p=$ 0.19 , Fischer's Exact Test).

Patients from group II (admitted in the hospital for fractures) were older (78.2 \pm 9.3 years) and showed lower levels of natremia $(138.7 \pm 3.3 \mathrm{mmol} / \mathrm{L})$; prevalence of hyponatremia was highest in this group (12 out of 92 patients, 13.04\%).

Hyponatremic patients $(n=19,7.3 \%, 3$ men / 16 women) had a mean age $74.3 \pm 13$ years, mean serum sodium levels $129.5 \pm 7.5 \mathrm{mmol} / \mathrm{L}$ (range 106-134.18 $\mathrm{mmol} / \mathrm{L}$ ) and 14 fractures (one vertebral, one distal forearm, 12 hip fractures). Differences between hyponatremic and normonatremic patients were presented in table 2.

Hyponatremic patients were significantly older and had significantly higher prevalence of fractures $(73.7 \% \mathrm{Vs}$. $42.7 \%, p=0.0147$, Fisher's Exact Test).

Unadjusted odds ratio for fractures in patients with hyponatremia was 3.75 [95\% C.I.: 1.3-10.75], $p=0.0138$. Unadjusted odds ratio for hip fractures in patients with hyponatremia was 3.65 [95\% C.I.: 1.38-9.64], $p=0.0089$. Unadjusted odds ratio for osteoporosis in patients with hyponatremia was 2.55 [95\% C.I.: 0.72-9.02], $p=0.14$. Diuretic use was encountered in 7 patients $(36.8 \%)$; combined diuretic use (furosemide plus spironolactone) was recorded in 3 patients (15.8\%).

Mild hyponatremia is associated with increased risk of fractures. Both incidence and prevalence of hyponatremia increase with age, up to $20 \%$ in patients older than 80 years $[4,21,22]$.

Data of the present study were collected from three settings (one endocrine department and two emergency orthopedics departments) as it is well known that hyponatremia is a common disorder in emergency departments, especially in elderly [23].

In our series, mean serum natremia was $140.4 \pm 4.5$ $\mathrm{mmol} / \mathrm{L}$, similar to that reported by Kinsela [24] in a series of 1,408 women with and without fractures, who underwentbone densitometry. However, global prevalence of hyponatremia was higher in our study (7.3\% vs. $4.2 \%)$, due to the enrolment of a higher proportion of osteoporotic patients $(68.8 \%$ vs. $45 \%)$. In the reported series, hyponatremia was present in $11.9 \%$ (14 out of 117 patients) with fractures versus $3.5 \%$ ( 5 out of 143 patients) without fractures $(p=0.0147)$. Similar data were reported by Kinsela $(8.7 \%$ in those with fractures vs. $3.2 \%$ in those without fractures $(p<0.001)$, with hyponatremic patients having a 2.25 fold increased adjusted OR for fracture. After correction for confounding factors (age, T-score, chronic renal or liver disease, osteoporotic risk factors, smoking history, alcohol use, osteoporosis treatment), hyponatremia remained significantly and independently associated with fractures [24]. The same results were reported by Sandhu etal., in a study on 364 elderly patients presented to an emergency department. The incidence of hyponatremia was significantly higher in the fracture group (9.1\% vs. $4.1 \%)$, with a mean serum sodium of $131 \pm 2$ $\mathrm{mmol} / \mathrm{L}$ in fracture group [25].

The global prevalence of hyponatremia in our study group (7.3\%) was similar to that reported by Hoorn et al. in 5,208 elderly patients (7.7\%). Hyponatremic patients had an increased risk for both non-vertebral fractures (adjusted $\mathrm{OR}=1.61$ ) and vertebral fractures (adjusted $\mathrm{OR}=1.34$ ) [10].

In group II, admitted in the hospital for the presence of frailty fractures, aged $78.2 \pm 9.3$ years, prevalence of hyponatremia was even higher (13.04\%, 12 out of 92 patients), and the levels of natremia lower (138.7 \pm 3.3 $\mathrm{mmol} / \mathrm{L}$ ). Other studies found even a higher prevalence of hyponatremia in 249 patients older than 65 years, admitted in the hospital for hip fractures (16.9\%) vs. $4.6 \%$ in 44 ambulatory patients admitted for elective orthopedic surgery [26].

Increased prevalence of hyponatremia (19\%) was also reported in a series of 334 elderly patients (aged over 65 years) with hip fractures [27]. Similarly, in a published study on 513 cases of bone fracture after incidental falls in patients over 65 years, hyponatremia was found in $13.06 \%$ of cases with fractures and in only $3.9 \%$ of sex and agematched control group of ambulatory patients. Adjusted odds ratio (OR) for fractures was 4.16 [95\% C.I.: 2.24-7.71]. Causes of hyponatremia were idiopathic SIADH (35\%), diuretics $(35 \%)$, use of SSRI (16\%), salt depletion (6\%), secondary SIADH (4\%), potomania (3\%) antiepileptic drug (1\%) [28].

However, cases of severe hyponatremia were seldom reported in patients with osteoporotic fractures. In our study only 3 patients had serum sodium levels below $120 \mathrm{mmol} /$ $L$ and 6 patients (2.3\%) had serum Na+ levels d" $130 \mathrm{mmol} /$ L. Pre and postoperative hyponatremia bellow $130 \mathrm{mmol} /$ $L$ was reported by McPherson only on $2.8 \%$ of patients with hip fractures [29].

In 19 patients with hyponatremia (mean serum sodium $129.5 \pm 7.5 \mathrm{mmol} / \mathrm{L}$ ), diuretic use was encountered in 7 patients (36.8\%) and combined diuretic use (furosemide plus spironolactone) in 3 patients (15.8\%). In a series of 458 patients with 547 osteoporotic fractures reported by Arampatzis et al. [17], any diuretic agent, loop diuretics, spironolactone and amiloride were significantly more frequently used in osteoporotic fractures patients. Prevalence of hyponatremia increased with the number of diuretics taken [17]. Diuretic use was reported in $11.1 \%$ of hyponatremic patients and in $6.8 \%$ of normonatremic patients in NHANES III database [3].

Men were not significantly represented in our series ( 23 men vs. 237 women). However, a strong relationship between hyponatremia and osteoporotic fractures was recently proven in a cross-sectional and longitudinal analysis of 5122 men aged $\geq 65$ years, followed for up to 9 years. Hyponatremic men showed an increased risk for hip fractures (hazard ratio, $H R=3.04$ ), prevalent $(O R=$ 2.46) and incident ( $O R=3.53$ ) morphometric spine fractures, but not nonspine fractures $(O R=1.44)$, independent of BMD [14].

In our series, $O R$ for fractures in patients with hyponatremia was 3.75 [95\% C.I.: 1.3-10.75], and for hip fractures was 3.65 [95\% C.I.: 1.38-9.64]. OR for osteoporosis in patients with hyponatremia was 2.55 [ $95 \%$ C.I.: 0.72-9.02], but was not significant statistically. The risks were similar with those calculated by Verbalis analyzing the Third National Health and Nutrition

\begin{tabular}{|c|c|c|c|}
\hline & Hyponatremic patients & Normonatremic patients & $\bar{P}$ \\
\hline n (\%) & $19(7.3 \%)$ & $241(92.7 \%)$ & - \\
\hline Men / Women & $3 / 16$ & $20 / 221^{--}$ & $0.23^{*--}$ \\
\hline Age (years) & $74.3=13$ & $65.9 \pm 12.6$ & $0.006^{* *}$ \\
\hline $\mathrm{Na}^{-}(\mathrm{mmol} / \mathrm{L})$ & $129.5 \pm 7.5$ & $141.2 \pm 2.7$ & $0.0001^{* *}$ \\
\hline No. of fractures, $\mathbf{n}(\%)$ & $14(73.7 \%)$ & $103(42.7 \%)$ & $0.0147^{*--}$ \\
\hline
\end{tabular}

Table 2

CHARACTERISTICS OF HYPO- AND NORMONATREMIC PATIENTS 
Examination Survey (NHANES III) database by linear regression models. Mild hyponatremia ( $133 \mathrm{mEq} / \mathrm{L}$ ) was associated with increased OR of osteoporosis at the total hip (OR = 2.85; 95\% C.I.: 1.03-7.86, $p=0.043)$ and at femoral neck (OR $=2.87$; 95\% C.I.: 1.41-5.81, $p=0.003$ ), after adjustments for age, sex, race, body mass index, physical activity, history of diuretic use, smoking, serum $25 \mathrm{OH}$ vitamin D levels. In hyponatremic patients, there was also a positive linear association between natremia and total hip and femoral neck BMD $(p<0.01)$, that was not find in normo-natremic patients $(p=0.99)$. In hyponatremic patients, total hip BMD decreased by 0.037 $\mathrm{g} / \mathrm{cm}^{2}$ for every $1 \mathrm{mmol} / \mathrm{L}$ decrease in serum sodium levels [3].

In a cohort study on 5,610 patients, hyponatremia was associated with a significant lower T-score at total hip in the multivariate analysis, and a borderline significant lower T-score atfemoral neck; how ever, there was no association between hyponatremia and lumbar spine T-score. In the same series, hyponatremia was associated with an increased HR for major osteoporotic fractures in women, ranging from 6 months before and 12 months after sodium measurement [30].

Other study also found that chronic mild hyponatremia (130-137 mmol/L) was associated with low bone mineral content and low bone mineral density for hip (both trochanteric, femoral neck and total hip), but had limited effect on the lumbar spine [31].

The present study results support the epidemiologic association of mild chronic hyponatremia and fractures in elderly.

A meta-analyis of 15 studies involving a total of 212,209 participants found a significant association of fracture and osteoporosis in patients with hyponatremia with OR of fracture $=1.99$ ( $95 \%$ C.I.: $1.50-2.63 ; p<.001)$ for studies that reported $\mathrm{OR}$, and increase risk of fracture with $\mathrm{HR}=$ 1.62 (95\% C.I.: 1.28- 2.05; $p<.001$ ) for studies that reported $\mathrm{HR}$ [32].

A recently published meta analysis of 15 studies, including 51,879 patients, of whom 2,329 were hyponatremic, showed that hyponatremia was associated with significantly increased risk of falls, especially in hospitalized patients $(O R=2.44)$. The estimated risk of falls related to hyponatremia was already significantly higher when a serum [ $\left.\mathrm{Na}^{+}\right]$cut-off of $135 \mathrm{mmol} / \mathrm{L}$ was considered $[O R=1.26(1.23 ; 1.29)]$, as it was also the cut-off of our series. The presence of hyponatremia was also associated with a higher risk of fractures, particularly hip fractures [MH-OR $=2.00$ (1.43; 2.81)] [33].

In the future, hyponatremia may be considered as a risk factor for osteoporotic fracures, mainly for hip fractures, together with classic risk factors (increased age, gender, low body mass index, low femoral BMD, previous fractures, alcohol use, glucocorticoid use, rheumatoid arthritis, secondary osteoporosis, falls, low calcium and vitamin D intake) [1]. Because of the increased number of studies showing a relationship between hyponatremia and fractures, it has been proposed to study whether hyponatremia (taking into account both its severity and duration) could be a potential biochemical risk factor for hip fractures, to be included in FRAX algorithms [34].

Physicians treating elderly patients at risk of hyponatremia and also orthopedic surgeons must be aware of the impact of mild chronic hyponatremia on bone metabolism $[1,11]$.

\section{Conclusions}

Elderly people with osteoporotic fractures should have serum sodium measurement; monitoring natremia in patients with osteoporosis and diuretic therapy is mandatory.

\section{References}

1.AYUS, J.C., NEGRI, A.L., KALANTAR-ZADEH, K., MORITZ, M.L., Nephrol. Dial. Transplant, 27, 2012, p. 3725.

2.UPADHYAY, A., JABER, B.L., MADIAS, N.E., Am. J. Med., 119, 2006, S30-S35.

3.VERBALIS, J.G., BARSONY, J ., SUGIMURA, Y., TIAN, Y.,.ADAMS, D.J ., CARTER, E.A., RESNICK, H.E., J. Bone Miner. Res., 25, 2010, p. 554. 4.CHEN, L.K., LIN, M.H., HWANG, S.J., CHEN, T.W., J. Chin. Med. Assoc., 69, 2006, p. 115.

5.KLEINFELD, M., CASIMIR, M., BORRA, S., J. Am. Geriatr. Soc., 27, 1979, p. 156.

6.MILLER, M., MORLEY, J .E., RUBENSTEIN, L.Z., J. Am. Geriatr. Soc., 43, 1995, p. 1410.

7.MILLER, M., HECKER, M.S., FRIEDLANDER, D.A., CARTER, J.M., J. Am. Geriatr. Soc., 44, 1996, p. 404.

8.MORITZ, M.L., AYUS, J.C., Nephrol. Dial. Transplant, 18, 2003, p. 2486.

9.COWEN, L.E., HODAK, S.P., VERBALIS, J.G., Endocrinol. Metab. Clin. North Am., 42, 2013, p. 349.

10.HOORN, E.J., RIVADENEIRA, F., VAN MEURS, J.B., ZIERE, G., STRICKER, B.H., HOFMAN, A., et al., J. Bone Miner. Res., 26, 2011, p. 1822.

11.ZAINO, C.J., MAHESHWARI, A.V., GOLDFARB, D.S., Am. J. Orthop. (Belle Mead NJ), 42, 2013, p. 522.

12.AYUS, J.C., MORITZ, M.L., Clin. J. Am. Soc. Nephrol., 5, 2010, p. 167.

13.SEJ LING, A.S., THORSTEINSSON, A.L., PEDERSEN-BJ ERGAARD, U., EIKEN, P., J. Clin. Endocrinol. Metab., 99, 2014, p. 3527.

14.J AMAL, S.A., ARAMPATZIS, S., HARRISON, S.L., BUCUR, R.C., ENSRUD, K., ORWOLL, E.S., et al., J. Bone Miner. Res., 30, 2015, p. 970.

15.BARSONY, J., SUGIMURA, Y., VERBALIS, J.G., J. Biol. Chem., 286, 2011, p. 10864.

16.SUGIMURA, Y., Clin. Calcium, 23, 2013, p. 1293.

17.ARAMPATZIS, S., GAETCKE, L.M., FUNK, G.C., SCHWARZ, C., MOHAUPT, M., ZIMMERMANN, H., et al., Maturitas, 75, 2013, p. 81.

18.BORGENS, R.B., Science, 225, 1984, p. 478.

19.TAMMA, R., SUN, L., CUSCITO, C., LU, P., CORCELLI, M., LI, J., et al., Proc. Natl. Acad. Sci. U.S.A., 110, 2013, p. 18644.

20.BARSONY, J., MANIGRASSO, M.B., XU, Q., TAM, H., VERBALIS, J.G., Age (Dordr), 35, 2013, p. 271.

21.HAW KINS, R.C., Clin. Chim. Acta, 337, 2003, p. 169.

22.MANNESSE, C.K., JANSEN, P.A., VAN MARUM, R.J ., SIVAL, R.C., KOK, R.M., HAFFMANS, P.M., et al., Maturitas, 76, 2013, p. 357.

23.NELSON, J.M., ROBINSON, M.V., Int. Emerg. Nurs., 20, 2012, p. 251. 24.KINSELLA, S., MORAN, S., SULLIVAN, M.O., MOLLOY, M.G., EUSTACE, J.A., Clin. J. Am. Soc. Nephrol., 5, 2010, p. 275.

25.SANDHU, H.S., GILLES, E., DEVITA, M.V., PANAGOPOULOS, G., MICHELIS, M.F., Int. Urol. Nephrol., 41, 2009, p. 733.

26.TOLOUIAN, R., ALHAMAD, T., FARAZMAND, M., MULLA, Z.D., J. Nephrol., 25, 2012, p. 789.

27.AICALE, R., TARANTINO, D., MAFFULLI, N., Med. Princ. Pract., 26, no. 5, 2017, p. 451. DOI: 10.1159/000480294.

28.GANKAM, K.F., ANDRES, C., SATTAR, L., MELOT, C., DECAUX, G., QJ M, 101, 2008, p. 583.

29.MCPHERSON, E., DUNSMUIR, R.A., Scott. Med. J., 47, 2002, p. 115. 30.HOLM, J.P., AMAR, A.O.S., HYLDSTRUP, L., J ENSEN, J E.B., Osteoporos Int., 27, no. 3, 2016, p. 989. DOI: 10.1007/s00198-015-33700.

31.KRUSE, C., EIKEN, P., VERBALIS, J., VESTERGAARD, P., Bone, 84, 2015, p. 9. DOI: 10.1016/j.bone.2015.12.002.

32.UPALA, S., SANGUANKEO, A., J. Clin. Endocrinol. Metab., 101, no. 4, 2016, p. 1880. DOI: 10.1210/jc.2015-4228.

33.CORONA, G., NORELLO, D., PARENTI, G., SFORZA, A., MAGGI, M., PERI, A., Clin. Endocrinol. (Oxf)., 89, no. 4, 2018, p. 505. DOI: 10.1111/ cen.13790.

34.AYUS, J.C., BELLINDO, T., NEGRI, A.L., Osteoporos Int., 28, no. 5, 2017, p. 1543. DOI: 10.1007/s00198-017-3907-5.

Manuscript received:21.08.2018 